\title{
Governing Divorce Practices of Somali Finnish Muslims: Does Religious Literacy Matter?
}

\author{
Mulki Al-Sharmani and Sanna Mustasaari
}

\begin{abstract}
This chapter employs the concept of religious literacy to examine the divorce practices of Finnish Muslims of Somali background and the roles mosques play in issuing religious divorces. Drawing on field-based research, we argue that Finnish Somalis, in their divorce practices, make use of both Islamic and civil state laws, adopting non-binary approach towards both systems. We problematize the essentialist notion of Islamic family law that is posited in opposition to secular state codes, which one often finds in public debates on Islam and family law. We examine, furthermore, how women's unequal access to divorce (compared to men) in Islamic law works in the Finnish context. In relation to this, we shed light on the complexities of the role and authority of mosques in issuing religious divorces to women when their husbands do not consent. We note that women's agency and access to divorce are not merely determined by the legal systems but also by the intersecting structures of power relations and resources in their lives. We conclude with some final reflections on the relevance of the concept of religious literacy with regards to our findings.
\end{abstract}

Keywords Religious literacy • Islamic family law • Muslim divorce • Gender • Governance of Islam

\section{Introduction}

Research on Muslim marriage and divorce practices in Finland is recent (Al-Sharmani 2015, 2017; Al-Sharmani and Ismail 2017; Al-Sharmani et al. 2017; Mustasaari and Al-Sharmani 2018; Al-Sharmani 2019). The concept of religious literacy, in particular, has not yet been explored in investigating Muslim marriage and divorce practices in Finland or in the larger European context. In this chapter, our aim is to fill this gap. Focusing on Somali Muslims' divorce practices in Finland, we examine the relevance of the concept religious literacy to the understanding of Muslim family practices in Finland and the related issue of the governance of Islam in the country.

M. Al-Sharmani $(\bowtie) \cdot$ S. Mustasaari

University of Helsinki, Helsinki, Finland

e-mail: mulki.al-sharmani@helsinki.fi 
We use the concept religious literacy to shed light on the complex, dynamic and non-binary relationship of Islamic family law to relevant Finnish civil codes as demonstrated in the divorce practices of our interlocutors. Somali Finnish women and men often divorce (and marry) in ways that integrate the two legal systems rather than positing them in opposition to one another. We also highlight how the concept can be helpful in de-essentializing Islamic family law with regard to women's agency. Thus we show how Somali Muslim women's access to Islamic divorce is not necessarily or singularly impacted by the unequal divorce rights of women and men in Islamic legal tradition but rather by a combination of factors that differentiate women's access to family-based resources and knowledge of the two legal systems.

Our analysis is based on field research conducted as part of an Academy of Finland project (2013-2018), which investigated how Muslims in Finland organize marriage and divorce in transnational space and how the Finnish state understands and facilitates their wellbeing. ${ }^{1}$ In particular, we draw on interview data collected from divorced women and men and from family dispute mediators in 5 mosques, ${ }^{2}$ in the period from 2013 to 2016 as well as four year ethnographic research in one Helsinki mosque focusing on its program for family wellbeing (which includes mediation and adjudication work in divorce cases). ${ }^{3}$ Our arguments are also informed by data collected by the authors of this chapter from interviews conducted in 2017 with leading religious actors in 8 mosques on their work in solemnization of marriages.

We structure the chapter as follows: The first section outlines how we understand and use the concept of religious literacy. The second section describes the Finnish context with regard to governance of religious minorities and in particular Muslim communities. We also outline the state policies governing marriage and divorce. The third section presents our analysis of the divorce practices of Somali Muslims in Finland, using the concept of religious literacy. We conclude with reflections on the relevance of religious literacy for scholarly and political debates about family law in Finland and in Europe.

\footnotetext{
${ }^{1}$ This project was titled 'Transnational Muslim Marriages in Finland: Wellbeing, Law, and Gender.' The first author was the lead researcher in the four year sub-study titled 'Transnational Somali Families in Finland: Discourses and Lived Realities of Marriage.' The second author was the post-doctoral researcher in the sub-study 'Governing Plurality: Marriage Practices and law.'.

${ }^{2}$ This research took place in the period from 2013 to 2017 . The first author conducted semi-structured interviews with 5 divorced women and life story interviews with 5 additional divorced women. Postdoctoral researcher, Abdirashid Ismail conducted semi-structured interviews with 5 divorced men. We are also informed by related data collected from interviews with 16 married women and men $(8$ each), conducted by the first author and Abdirashid Ismail. The first author and Abdirashid Ismail also conducted interviews with members of family dispute resolution committees in 5 mosques in Helsinki.

${ }^{3}$ The first author conducted this ethnographic research in the course of four years, which consisted of participant observation as well as interviews with the mosque program organizers and participants.
} 


\section{Religious Literacy}

One of the main functions of the concept of religious literacy as an analytical tool, according to Adam Dinham and Matthew Francis, is to critique the notion of religion as a problem, and to rethink the role of religion in the public sphere, arguing that the boundary between the secular and the religious is not given or fixed (Dinham and Francis 2015, 3).

Moore (2006, 2015) equally affirms the importance of understanding the ways in which religion is embedded in everyday life. Moore views religious literacy as the ability to "discern and analyze the fundamental intersections of religion and social/political/cultural life through multiple lenses." (Moore 2006, 1.)

The editors of this volume also put forward religious literacy as an important conceptual lens to avoid two serious analytical pitfalls, particularly in relation to governance of religious diversity. These pitfalls are: failing to recognize the relevance of religion and how to engage with it; or over-determining its role and significance in the lives of religious minorities.

We concur with the above-mentioned scholars. We contend religious literacy is not only limited to correctly understanding when and how religion plays a role in diverse social processes. It also goes beyond having adequate knowledge of relevant religion in a relevant context. Religious literacy, we argue, is also about acquiring an informed understanding about the often dynamic and processual relationship that members of a religious community have with their religious tradition. Hence, in this chapter, we use religious literacy not to reveal some inherent truth about Islamic family law, but rather to unpack and problematize essentializing notions about Muslim family norms and practices and show how Islamic family law interacts in dynamic and nonbinary ways with the relevant Finnish civil codes, as our Somali Muslim interlocutors navigate both civil and religious divorce.

We also note how religious understandings may evolve as part of a process of reengaging with one's religious tradition in a new context where multiple factors are at play. For instance, some mosques - in their roles as officially registered religious communities undertaking the responsibility of attending to the spiritual needs as well as the integration of Muslim families into the larger society-promote Muslim marriage and divorce practices that combine and reconcile between Islamic and Finnish laws. And some individuals also adopt new religious understandings whereby both Islamic family law and civil Finnish code have equal and connected role in regulating marriages and divorces. Moreover, these understandings are acquired through individual efforts to lead an Islamic ethical life (Al-Sharmani 2019). Such shifts in religious understandings can perhaps be understood as part of an internal process within the Somali Muslim community effort to reshape Islamic norms regarding marriage and divorce as they navigate life of a religious minority in the Finnish context and where Islam has recently been framed as 'a problem' (Martikainen 2014; Al-Sharmani 2015). This internal process is what the Dutch scholar Veit Bader calls 'internal religious governance.' (Bader 2007, 874.) 


\section{Multi-religious Finland and Governance of Muslim Marriages}

In 1923, Finland issued its first Freedom of Religion Act. This law affirmed the equal right of individual citizens and communities to claim and practice their religion freely. Eighty years later with the issuing of the new Freedom of Religion Act of 2003, a new state discourse emerged that foregrounds 'positive religious freedom.' The country's new constitution, passed in 2000, also highlights the state's responsibility to support and strengthen the religious rights and identities of the diverse communities in the country (Kääriäinen 2011, 158).

Perhaps one effect of this new framework for governing religious pluralism in the case of Muslim communities has been that the number of mosques registered as religious communities increased from a handful in the early 1990 s to over 50 in 2010 (Ketola et al. 2014). Accordingly, there has been more visible role for mosques in solemnizing Muslim marriages, mediating and adjudicating in divorce cases, and involvement with families in various activities targeting married couples, parents, and children (Al-Sharmani 2019). This does not mean that the work of mosques with families is solely motivated or enabled by these policies, but it does mean that these policies created legal and discursive space for the work of mosques in these aspects.

Marriage and divorce in Finland are regulated in the 1929 Marriage Act (234/1929). Historically, the state had no role in solemnizing marriages; this task belonged to Christian church alone. The situation changed as late as in the early 20th Century, and the 1929 Marriage Act gave all religious communities the right to solemnize marriages, with a permit granted by the government. For mosques, the right to solemnize marriage was particularly strengthened after they were able to register as religious communities according to the 2003 of Freedom of Religion Act, rather than registering as associations according to the 1989 Associations Act. In 2008, a law was passed to further regulate the solemnization of religious marriages (2008/571, after 1 January 2020,1157/2019). The new law stipulates that mandate or license to solemnize marriages is granted to a person who is member in a registered religious community, provided that the registered religious community supports the permit. After the marriage ceremony, the marriage certificate must be taken to the local register office and inserted into the population register. ${ }^{4}$

Unlike marriage, legally recognized divorce belongs to the sole jurisdiction of the state. A divorce is issued by a district court upon a petition. No grounds for divorce are required, but there is an obligatory reconsideration period of 6 months, during which the divorce petition is kept pending. After the waiting period ends, the divorce is issued automatically if the spouses or one of them renews the application. If the spouses have lived separately for two years, the divorce is issued without a reconsideration period. Religious communities do not have the legal authority to issue state-recognized divorce, and the scope for private agreements about, for example,

\footnotetext{
${ }^{4}$ Contrary to some other European states, such as the UK, cases concerning disputes about the legal validity of religious marriages solemnized in Finland have not been reported in the courts (see for discussion, Mustasaari and Vora 2019).
} 
arbitration or applicable law is very limited. Hence, for Muslims in Finland, it is often a case of legal pluralism where individuals use both Finnish and Islamic legal systems to organize their marriages and divorces. We elaborate this further in the following section.

\section{Somali Muslim Divorce Practices}

Somalis in Finland, for the most part, settled in the country since the late 1980s and onwards through refugee migration and subsequent family reunification, following the Somali Civil War of the late 1980s and early 1990s. With a total number of over 18,000 , Somalis are the third largest migrant group in the country after the Russians and Estonians. They are also the largest Muslim community in the country where the total Muslim population is estimated around 100,000. This is a community that has been confronting a host of challenges such as low employment rate, low economic mobility, and racism (OSF 2013).

Somali women and men in Finland, predominantly, follow a two tier-system in their practices of concluding both marriage and divorce (Mustasaari and Al-Sharmani 2018). When marrying, some couples conclude the marriage at one of the licensed mosques, which then takes on the responsibility to do the paperwork needed to register the marriage at the local register office. Other couples have their marriage solemnized by an individual religious scholar, who may or may not be affiliated with licensed mosques. This usually takes place either in the family home or a rented party hall. Then the couples themselves take on the task of following the procedures for registering the marriage at the local register office.

In the case of divorce, couples also follow a two tier process. They conclude a civil divorce as well as Islamic one. There is no particular consequence that couples follow in concluding both divorces. In some of cases, for example, a wife would seek an Islamic divorce from her husband and the latter would agree to it. The husband would then pronounce the divorce in the presence of the wife and some of her family members, and then he would write a letter attesting to the conclusion of the divorce. Then the wife would initiate the civil divorce procedures. In other cases, the wife would initiate the civil divorce procedures and then would secure the Islamic divorce from the husband.

Most of our interlocutors see both Islamic and Finnish legal systems as important in their lives. Following Islamic legal rulings is viewed as an integral part of living a Muslim life and of being part of the Somali community in Finland. Abiding by the Finnish civil code is described as part of an effort to strengthen one's place in the society as a racialized citizen, and to facilitate the ability to claim certain citizenship rights such as family reunification in the case of marriage or the ability to officially remarry in the case of divorce.

Additionally, some of the interlocutors adopt a religious interpretation that advocate adherence to both legal systems in an integrated way as an ethical Muslim duty, rather than a practical necessity. This kind of religious understanding is being put 
forward by some of the mosques as well as increasingly being articulated by young educated women who are actively pursuing religious knowledge. (Al-Sharmani 2017; Al-Sharmani et al. 2017; Mustasaari and Al-Sharmani 2018; Al-Sharmani 2019.)

By using the concept of religious literacy to interpret the above-mentioned findings, firstly we can steer clear from a reductionist understanding that posits Islamic law in an oppositional relationship with Finnish civil code. Our interlocutors (whether individuals or mosques) are not approaching the two legal systems as totally separate but rather as belonging to one process through which couples navigated divorce. Secondly, one has to take into account the underlying social, historical, and policyrelated factors shaping this approach. This is a context where many of the marrying and divorcing couples are immigrants or children of immigrants who do not have experience with codified Islamic family law. Instead, for the most part they organize their religious marriages and divorces drawing on uncodified juristic doctrines from Islamic legal tradition in fluid and decentralized ways. This, we put forward, may be facilitating their flexible non-binary approach towards both legal systems unlike a situation where couples have to engage with two state systems to secure both kinds of divorce. Thirdly, this is an immigrant community that has settled in Finland fairly recently and who is striving for inclusion and social mobility in the larger society where they confront racism, economic vulnerabilities, and to some extent Islamophobia. And, finally, this is taking place in a context where state policies promote and enable the participation of registered religious communities in the work of governance and creating social cohesion, particularly through the work of these communities with families (Al-Sharmani 2019).

When women need to secure Islamic divorce from unwilling husbands, civil divorce alone is not sufficient since women still need to severe the marital bond according to Islamic law. But how are women in such cases impacted by the unequal divorce rights in Islamic legal tradition which privilege men? In Islamic jurisprudence, men can sever the marital bond extra judicially through unilateral repudiation (tala $q$ ). The divorce becomes final with the end of a waiting period ( 'idda) that a woman observes after the pronouncement of the divorce, which is three menstrual cycles. Women, on the other hand can petition for judicial divorce (tatli $q$ ) on specific fault-based grounds. Women can also initiate divorce $\left(k h u l^{\circ}\right)$ and secure it with the consent of the husband in exchange for giving up their dower and post-divorce financial dues (Ali 2006). Both parties can also reach a mutual agreement to divorce that entails a particular financial settlement $(i b r \bar{a})$, often releasing the husband from some or all his financial obligations towards the wife.

This legal construction certainly makes men and women's access to divorce unequal in Islamic jurisprudence. To put in check the privileges granted to the husband, early Muslim jurists saddle him with hefty post-divorce financial dues owed to the wife particularly if she does not consent to the divorce or is not responsible for the martial rift. In contemporary Muslim majority countries, varying legal changes have been introduced to the codified family laws, which draw on Islamic jurisprudence, to restrict men's right to unilateral repudiation and to expand women's divorce rights (Tucker 2008; Welchman 2015). Nonetheless, many Muslim majority 
countries still uphold unequal divorce rights. This also applies to Somalis in Finland, who draw on uncodified Islamic juristic rulings to regulate their divorces. ${ }^{5}$

Our data, however, shows that it is not necessarily women and men's unequal divorce rights in Islamic law that primarily determine women's access to Islamic divorce. Rather it is a combination of factors that differentiates women's access to resources and knowledge, which in turn impacts their access to Islamic divorce. We elaborate on this point through the following example from our interview data:

$\mathrm{Jamila}^{6}{ }^{6}$ a forty-two year old Finnish citizen of Somali background, was married for over a decade and was mother of three children when she decided to end her marriage. Jamila moved to Finland when she was in early twenties as the bride of a Finnish citizen of Somali background. The couple got married by an individual scholar in Somalia. They then concluded an official Islamic marriage in a notary office of an Eastern African country where they applied for family reunification visa for Jamila.

The marriage was not a happy one: Jamila's husband did not want her to be involved in managing their finances; was opposed to her wishes to pursue studies and work; and spent considerable amount of his salary on outings with his friends. When Jamila decided to get divorced, she knew she wanted to secure both a civil and Islamic divorce. Being a Finnish citizen with a life and children in Helsinki, securing a legally recognized divorce was an integral part of Jamila's efforts to start an autonomous life, and to be able to petition for child alimony. But securing the civil divorce was not enough. According to her religious beliefs, Jamila also believed that her marriage bond could only be fully severed with the securing of an Islamic divorce.

Jamila secured the civil divorce, but the Islamic one was challenging. Her husband refused to divorce her, and there were no family members to whom Jamila could resort and use their support as leverage to negotiate with the husband for divorce. Finally, Jamila decided to resort to one of the main mosques in Helsinki. The mosque family dispute committee called the husband and sought to meet with him to discuss his wife's petition for divorce. The husband was belligerent, rejecting the mosque's authority as a mediator and arbiter in the divorce dispute and even threatening the family dispute committee with violence. The mosque mediators repeatedly tried to reason with Jamila's husband. Few months later, the husband called Jamila and told her he did not want the mosque to be involved, to save his face in the community. In exchange for her withdrawing the divorce petition from the mosque committee, he divorced her by making the pronouncement in her presence and her neighbor, as well as writing a letter attesting to affecting the Islamic divorce.

\footnotetext{
${ }^{5}$ The majority of the interlocutors were married in Finland. The few marriages that took place in Somalia happened long after the Somali Civil War when the Somali Family Law of 1975 was no longer applicable with the collapse of the Barre regime.

${ }^{6}$ The names of the interlocutors quoted in this chapter are fictitious. Life story interview conducted by the first author in the period from 2014 to 2016.
} 
Jamila's case reveals few noteworthy things. On the one hand, it illustrates the interconnectedness of the Islamic and Finnish civil codes in Somali divorce practices. Jamila could not consider herself divorced and move forward with her life without securing both divorces. On the other hand, her access to Islamic divorce was challenged partly because of men and women's unequal divorce rights in Islamic jurisprudence. But reading Jamila's case as a simple incongruence between Finnish and divorce laws would be misleading. Jamila's challenges also had to do with multiple factors that illustrate the need for a religious literacy that takes cognizance of the sociopolitical context in which her life was embedded.

It is a context where mosques as registered religious communities do not have the authority to issue legally binding Islamic divorce. In addition, it is a context where Jamila has no access to a court system where she can petition for Islamic judicial divorce. One could ask: do mosques need Finnish state authority to be recognized by members of their registered religious communities as having the authority to issue an Islamic divorce? The answer is not straightforward and points us to a number of underlying issues. It shows that what is religious law and how its authority is shaped and recognized is contextualized and layered. It also sheds light on the contestations around mosques as the moral actor fit to mediate and arbitrate in family disputes. On the one hand the model of Finnish governance of religious pluralism creates space for mosques to undertake this role notwithstanding their circumspect legal authority. On the other hand, the divorce (and marriage) practices of many Somalis also show that mosques are not always and necessarily the main body that undertakes the work of marriage and divorce conclusion. Many couples resort to a network of family relatives and individual religious scholars to navigate their divorces (as well as conclude their marriages). And there are couples who purposefully avoid resorting to mosques, particularly those run by members of their ethnic groups, motivated by saving face and maintaining a sense of privacy within their own local community. This partly may explain why Jamila's husband was persuaded to divorce her so as not to prolong dealing with the mosque, which is predominantly run by and attended by Somalis.

Our final point is that it would be also misleading to simply attribute the challenges that some women like Jamila encounter in accessing Islamic divorce, to men and women's unequal divorce rights in Islamic law. We need to adopt an intersectional approach that de-homogenizes Muslim women. Part of Jamila's difficulties in securing Islamic divorce also had to do with her weak family support. Her father, a religious scholar who lived in East Africa, was able to mediate between the couple frequently and successfully via transnational means of communications. However, when he passed away, she lost that support.

Perhaps it is fruitful to compare Jamila's case to another interlocutor, Deeqo ${ }^{7}$ a thirty year old Somali woman who grew up in Finland. Deeqo moved to Finland when she was very young, attained high level of education, and was well-versed in Islamic religious knowledge. When Deeqo's marriage broke down and she decided to get an Islamic divorce, she encountered no difficulties, as she explained to the first

${ }^{7}$ Life story interviews conducted by the first author in the period from 2014 to 2016 . 
author. She explained that her family was supportive and were available for her as they lived in Finland. The husband, furthermore, could not afford to be belligerent and refuse the divorce, as Deeqo's family was fairly well-known and respected in the local community. Deeqo also emphasized that she knew her Islamic rights very well, and believed that her husband could not keep her in a marriage that she did not want. Deeqo's example shows us that her social resources, which were superior to Jamila's, enabled her to make religious-legal claims and interpret the law as being on her side. Accordingly, Deeqo and Jamila's encounters with Islamic law in a secular Finnish context were quite different.

\section{Final Reflections on Religious Literacy and Governance of Islamic Family Law}

In European debates, religious_-especially Islamic_family laws or norms are often depicted as problem or exception to the norm of "secular" or "neutral" law (Bano 2017; Grillo 2015; Bredal 2018; Shah et al. 2014). In the Nordic context too, Islamic family law is increasingly represented as an "anomaly of secular society" (Bredal 2018; Mustasaari 2019; Mustasaari and Al-Sharmani 2018; Moors and Vroon-Najem 2019). The problem of this approach is that it depicts secularism as the normative ideal while failing to take into account the local historical particularities that define "secularism" in relation to (some form of) religion (Mahmood 2015) and in the process construct the distinction between private and public spheres. Accordingly, this approach denies that there is any relevance for religion in the public sphere and sees religion and religious norms as characteristic of the immigrant "other".

In May 2018, for example, the Finnish Minister of Justice Antti Häkkänen, who spoke in the ETNO-forum organized by the advisory board of Ethnic Relations, stated that while Finland is an open and diverse society, there is no room in it for Shari 'a Law. The Minister made the statement in the context of warning against a 'parallel society' where, for example, forced marriage and female genital mutilation take place and are condoned (YLE 2018). Such polarizing discourse seems to prevail despite the research-based evidence, which clearly points towards multidimensional and often mutually constitutive interrelationships of secular and religious law instead of an oppositional relationship of law and parallel legal systems (Bano 2017; Bredal 2018; Mustasaari and Al-Sharmani 2018).

These contemporary debates about Islamic family law whether in Finland or in the larger European context, in our view, are prime examples of religious illiteracy. Through adopting and repeating pathologizing assumptions and imagery of threat that Muslim family life allegedly embodies, religious illiteracy plays a key role in the process of legitimizing the marginalization of Muslims in European societies. Furthermore, as Melloni reminds us, similar to basic illiteracy, religious illiteracy can effectively be used as a tool of public policy not to extend political participation and civil development (Melloni 2019,6). When in political speech Islamic law is 
framed as a key threat that Western societies are facing, it is not only Muslims that are being marginalized. Using promises of protection against the imaginary threat of Islamic law as bait in political campaigns is to use religious illiteracy to mislead the members of the public from debating issues that actually and urgently require social reforms.

Thus, religious literacy is useful in shedding light on the layered ways in which law (whether religious or secular) functions in the everyday life of Muslim immigrants. Our findings show that religion (in this case Islam) matters as a source of norms regulating Somali intimate relationships. Women and men (with the help of their families and mosques) draw on Islamic law to divorce even though religious divorce is not recognized by the Finnish legal system. However, Islamic law and Finnish civil laws are also interconnected in Somali divorce practices. Securing both Islamic and civil divorce are important for many and the determining factors are multidimensional. They include: Finnish model of religious governance, the history of Somali migration to the country, the migrants' living conditions and challenges as religious and racialized minorities struggling for empowering membership in the Finnish society.

Our findings also show the importance of intersectionality in understanding how law (religious and secular) is at play in individuals' life. It is not simply egalitarian Finnish divorce laws or gendered Islamic divorce laws that shape Somali Muslim women's divorce claims and practices. Rather it is how these women are differentially situated with regard to structures of power and their access to relevant resources such as family support, knowledge of both legal systems, access to effective mosque mediation and adjudication.

Finally, religious literacy also entails taking note of how immigrants' religious understandings evolve and develop. In our study, the practice of applying and reconciling both Islamic and Finnish legal systems in divorce practices goes beyond fulfilling individuals' pragmatic needs. For some interlocutors, it has become part of a new understanding of Islamic law and pious pursuit of an ethical Muslim life.

\section{References}

Ali, K. (2006). Sexual ethics and islam: Feminist reflections on Qur'an, hadith, and Jurisprudence. Oxford: OneWorld.

Al-Sharmani, M. (2015). Striving against the 'Nafs': Revisiting Somali Muslim spousal roles and rights in Finland. Journal of Religion in Europe, 8, 101-120.

Al-Sharmani, M. (2017). Divorce among transnational Finnish Somalis: Gender, religion, and agency. Religion and Gender, 7(1), 70-87.

Al-Sharmani, M. (2019). A mosque programme for the wellbeing of Muslim families. In M. Tiilikainen, M. Al-Sharmani, \& S. Mustasaari (Eds.), Wellbeing of transnational Muslim families: Marriage, law and gender (pp. 59-77). London: Routledge.

Al-Sharmani, M., \& Ismail, A. (2017). Marriage and transnational family life among Somali Migrants in Finland. Migration Letters, 14(1), 38-49. 
Al-Sharmani, M., Mustasaari, S., \& Ismail, A. (2017). Faith-based family dispute resolution in Finnish mosques: Unfolding roles and evolving practices. In S. Bano (Ed.), Gender and justice in family law disputes: Women, mediation, and religious arbitration (pp. 270-291). Waltham, MA, USA: Brandeis University Press.

Bader, V. (2007). The governance of Islam in Europe: The perils of modelling. Journal of Ethnic and Migration Studies, 33(6), 871-886.

Bano, S. (2017). Women, mediation, and religious arbitration: Thinking through gender and justice in family law disputes. In S. Bano (Ed.), Gender and justice in family law disputes. Women, mediation, and religious arbitration (pp. 1-21). Waltheim, MA: Brandeis University Press.

Bredal, A. (2018). Contesting the boundaries between civil and religious marriage: State and mosque discourse in pluralistic Norway. Sociology of Islam, 6, 297-315.

Dinham, A., \& Francis, M. (2015). Religious literacy: Contesting an idea and practice. In A. Dinham \& M. Francis (Eds.), Religious literacy in policy and practice (pp. 3-26). Bristol: Policy Press.

Grillo, R. (2015). Muslim families, politics and the law: A legal industry in multicultural Britain. London: Routledge.

Ketola, K., Martikainen, T., \& Salomäki, H. (2014). New communities of worship: Continuities and mutations among religious organizations in Finland. Social Compass, 61(2), 153-171.

Kääriäinen, K. (2011). Religion and state in Finland. Nordic Journal of Religion and Society, 24(2), 155-171.

Mahmood, S. (2015). Religious difference in a secular age: A minority report. Princeton, NJ: Princeton University Press.

Martikainen, T. (2014). Muslim immigrants, public religion, and developments towards a postsecular Finnish welfare state. Tidsskrift for Islamforskning, The Nordic Welfare State, 8(1), 78105.

Melloni, A. (2019). European religious illiteracy. The historical framework of a removed agenda. In A. Melloni, \& F. Cadeddu (Eds.), Religious literacy, law and history. Perspectives on European pluralist societies (pp. 3-16). London: Routledge.

Moore, D. L. (2006). Overcoming religious illiteracy: A cultural studies approach. World History Connected, 4(1). Retrieved November 30, 2018, from http://worldhistoryconnected.press.illinois. edu/4.1/moore.html.

Moore, D. L. (2015). Diminishing religious literacy: Methodological assumptions and analytical frameworks for promoting the public understanding of religion. In A. Dinham \& M. Francis (Eds.), Religious literacy in policy and practice (pp. 27-38). Bristol: Policy Press.

Moors, A., \& Vroon-Najem, V. (2019). Converts, marriage, and the Dutch Nation-state: Contestations about Muslim women's well-being. In M. Tiilikainen, M. Al-Sharmani, \& S. Mustasaari (Eds.), Wellbeing of transnational Muslim families: Marriage, law and gender (pp. 22-38). Studies in Migration and Diaspora. London: Routledge.

Mustasaari, S. (2019). Extra-judicial muslim divorces and family mediation in the Nordic Countries: What role is there for the welfare state? In K. Boele-Woelki (Ed.), Plurality and diversity offamily relations in Europe (pp. 285-312). Cambridge: Intersentia.

Mustasaari, S., \& Al-Sharmani, M. (2018). Between 'Official' and 'Unofficial': Discourses and practices of muslim marriage conclusion in Finland. Oxford Journal of Law and Religion, 7(3), 455-478. https://doi.org/10.1093/ojlr/rwy029.

Mustasaari, S., \& Vora, V. (2019). Wellbeing, law and marriage: Recognition of Nikāh in multicultural Britain and the Finnish welfare state. In M. Tiilikainen, M. Al-Sharmani, \& S. Mustasaari (Eds.), Wellbeing of transnational Muslim families: Marriage, law and gender (pp. 39-58). London: Routledge.

OSF. (2013). Somalis in Helsinki. New York and London: Open Society Foundations. Retrieved January 2, 2018, from https://www.opensocietyfoundations.org/sites/default/files/somalis-hel sinki-20131121.pdf.

Shah, P., Foblets, M.-C., \& Rohe, M. (Eds.). (2014). Family, religion and law: Cultural encounters in Europe. Farnham: Ashgate. 
Tucker, J. (2008). Women, family, and gender in Islamic law. Cambridge: Cambridge University Press.

Welchman, L. (2015). Qiwamah and Wilayah as legal postulates in Muslim family laws. In Z. Mir-Hosseini, M. Al-Sharmani, \& J. Rumminger (Eds.), Men in charge? Rethinking authority in Muslim legal tradition (pp. 132-159). Oxford: OneWorld.

YLE. (2018). Justice Minister: "No room in Finland for Sharia law". Retrieved December 19, 2019, from https://yle.fi/uutiset/osasto/news/justice_minister_no_room_in_finland_for_sharia_ law/10218154. (22 May 2018).

Open Access This chapter is licensed under the terms of the Creative Commons Attribution 4.0 International License (http://creativecommons.org/licenses/by/4.0/), which permits use, sharing, adaptation, distribution and reproduction in any medium or format, as long as you give appropriate credit to the original author(s) and the source, provide a link to the Creative Commons license and indicate if changes were made.

The images or other third party material in this chapter are included in the chapter's Creative Commons license, unless indicated otherwise in a credit line to the material. If material is not included in the chapter's Creative Commons license and your intended use is not permitted by statutory regulation or exceeds the permitted use, you will need to obtain permission directly from the copyright holder. 